\title{
Determinants of Corporate Cash Holding of Non-Financial Firms Listed on the Nairobi Securities Exchange
}

\author{
Constantine Barasa ${ }^{1}$, George Achoki ${ }^{1} \&$ Amos Njuguna ${ }^{1}$ \\ ${ }^{1}$ Chandaria School of Business, United States International University Africa, Nairobi, Kenya \\ Correspondence: Constantine Barasa, Chandaria School of Business, United States International \\ University-Africa, P.O Box 24381-00100 Nairobi, Kenya. E-mail: bconie@yahoo.co.uk
}

Received: June 8, 2018

doi:10.5539/ijbm.v13n9p222
Accepted: July 11, 2018

Online Published: August 7, 2018

URL: https://doi.org/10.5539/ijbm.v13n9p222

\begin{abstract}
A general rise in the cash holding levels by firms internationally in the recent years has led to an increase in interest in cash holding research as cash is an asset that typically yields low return. Empirical research has produced mixed results and often little research has been carried out on the subject in developing countries. This paper thus looks at the determinants of cash holding of 44 non-financial firms listed in Nairobi securities exchange (NSE) for the period 2002 to 2013 using secondary data in annual reports and financial statements. We test for trade off, pecking order and the free cash flow theories using correlational and non-experimental research design. The results of OLS with year and industry dummies and panel data models shows that there exists significant positive and negative relationship between cash holding and cash flow and leverage respectively and insignificant relationship between cash holding and market-to-book value and firm size. Interest rests were found to be a significant mediator of the relationship between cash holding and MTB, size, leverage and cash flow. Industrial sector of a firm's main activity influences its cash holding policies. This study adds to the frontier knowledge on the determinants of cash holding by helping managers decide on their firm's optimal cash holding while also serving to inform investors on whether portfolio managers are adopting the right cash holding practices.
\end{abstract}

Keywords: cash holding, cash flows, leverage, market-to- book value, NSE

\section{Introduction}

\subsection{Background}

Cash is a low return asset compared to other investment opportunities and therefore holding excess liquidity is not an attractive position for most firms. However, the determination of an optimal cash holding is a puzzle to most managers (Saddour, 2006) especially with the heighted uncertainty. In the past managers who accumulated more cash holdings were viewed with a great deal of suspicion (Fresard, 2010) however, the recent waves of market turmoil and credit tightening has reversed this view as it is advantageous to maintain a liquid balance sheet to avert scenarios of cash squeeze.

The reasons why firms hold cash have been articulated through the liquidity preference theory where firms need cash to meet three main needs. Transaction needs where firms need cash to meet their normal expenses as and when they arise to ensure smooth operations (Afza and Adnan, 2007). Secondly firms also need cash to take care of unforeseen needs. Such precautionary balances are needed for instance during economic downturn and also in the event that external financing is not available. The final motive for holding cash is to meet speculative demand that seeks to take advantage of market opportunities as and when they arise.

The debate on how much cash to hold and what factors influence such cash holding has been going on for several decades. Earlier studies by Baumol (1952) and Tobin (1956) sought to set a target or optimal cash holding level for firms. This mainly focused on the tradeoff theory that sought to optimize the marginal benefits of holding cash and such target level would be set where the marginal benefits were equal to the marginal cost of holding cash (Myers, 1977)

Following the work of Myers and Majluf (1984) in which they proposed the pecking order theory of firm financing, capital structure is now considered a key influence in the cash holding decision of the firm. Specifically it is held that firms hold high cash balances to avoid having to raise funds from external sources. 
The importance of studying corporate cash holding of firms is rooted in the fact that in most firms it forms a significant portion of firm assets(Ozkan and Ozkan (2004) 14\%, Ditmar et al. ,(2003) 13\%, Lee and Lee, (2010) $12 \%$ and Kachleva and Lins (2007) 16\%). Management has easy access to cash balances and have an upper hand in the choice of how to apply them. Also cash balances fluctuate over time thus the need for planning for minimal balances required to meet transactional needs even with the fluctuations (Dittmar \& Smith, 2007). It is thus important that firms carry optimal cash balances as any excess may be misapplied because of the agency problem where managers do no act in the best interest of the owners of the firms (Jensen,1986)

From a competitive strategy approach, cash holding has been identified as an important strategic tool (Fresand, 2010). A company may use its cash to fund new products,channels and entry into new markets, superior pricing and errect bariers to entry among other strategic activities which can unnerve competition and therefore ensure continued prosperity of the firm (Benoit,1984).

In conclusion as research has progressed there has been a recognition that to give the transaction view a complete analysis there is need to recognize the existence of market imperfections including the risk of financial distress, information asymmetry and agency problem (Garcia-Teruel \& Martinez-Solano, 2008). All these factors influence cash holding decisions.

\subsection{Problem Statement}

In the recent year's firms have been found to increase their cash holding reserves. For instance, Sanchez and Yurdagul (2013) observe that by 2011, US firms were holding four times as much cash as they were holding in 1995. Daher (2010) finds that the cash to assets ratio of private firms in the UK almost doubled between 1994 and 2005. In South East Asia Lee and Lee (2010) notes that cash represents a substantial portion of corporate assets with firm's cash holding rising from eight percent in 1996 to twelve percent in 2005. The study by Ferreira and Vilela (2004), which uses a sample of Eurozone countries, reveals that non-financial European firms have on average around $15 \%$ of assets in cash holdings. Duchin (2010) reports that for the average cash holdings of stand-alone firms are almost double the cash holdings of diversified firms. Over the study period 1990 to 2006, diversified firms held on average $11.9 \%$ of their assets in cash, whereas stand-alone firms held more than $20.9 \%$ of their assets.

Some researchers (i.e. Dittmar, Mahrt-Smith and Servaes, 2003; Kusnadi \& Wei, 2011) have done cash holding studies using international samples but such studies were found not to have used adequate sample size to bring out the uniqueness of the local industry. For instance, Ditmar al., (2003) used one Kenyan company while Kusnadi and Wei (2011) did not use any company in Kenya in their sample. This study will thus provide for an opportunity to confirm previous research finding but in a Kenyan context which has not been adequately researched previously. It is thus important to explore the cash management practices in this country to establish if it conforms to extant literature and if not develop necessary regulatory policies that will influence cash behavior of corporates. This research therefore seeks to establish the cash holding patterns and its determinants among non-financial firms listed on the Nairobi Securities Exchange.

\subsection{Empirical Review}

A numbers of studies that have been undertaken on cashholding have sought to explain the firm characteristics that affect cash holding using three theoretical models: the trade-off model (Myers 1977) and the pecking order model (Myers \& Majluf 1984) and the free cash flow theory (Jensen 1986). Within the three theoretical models a number of determinants of cash holding have been developed: Investment opportunities, firm size, leverage, dividend payments, corporate governance parameters (Board size, CEO duality, and ownership structure and investor protection mechanisms), cash flow volatility, credit rating, interest rates, and financial constraints among others. In this study the determinants considered are investment opportunities, firm size, levarage and cash flows as independent variables. Interest rates and industry sector are tested as moderating variables.

\subsubsection{Effect of Market-to-Book Ratio on Cash Holding}

The market-to-book ratio is used as a proxy for investment opportunities in studies where there exists an active market to help determine objectively the market value of a firm in other studies especially for private firm the sales asset ratio has been used. The MTB is used because this study surveys firms listed in the stock exchange.

According to the transactional motive and precautionary motive, cash is beneficial for firms. Firms need cash to carry out their normal activities, to take advantage of profitable future investment opportunities, and to meet unforeseen events.

Under the pecking order theory a large investment opportunity set creates a demand for a large stock of cash, because cash shortfalls imply that unless a company engages in costly external financing it must forego 
profitable investment opportunities

In contrast, the free cash flow theory postulates that cash holdings are detrimental for firms, since cash holdings imply agency costs because managers have a large amount of funds under their control that may induce suboptimal practices (Martinez-Sola, Garcia-Teruel, \& Martinez-Solano, 2013). For instance managers of firms with poor investment opportunities can hold more cash to ensure the availability of funds to invest in growth projects, even if the NPV of these projects is negative.

Several studies have reported positive relations between cash holding and MTB which is used as a proxy for investment opportunities available to a firm. Ferreira and Vilela (2004) found that cash holdings are positively affected by the investment opportunity set. Rizwan and Javed (2011) for firms in Karachi Stock Exchange and Alam et al. (2011) found a positive relationship between market-to-book ratio and cash holdings. Gill and Shah (2012) from a sample of Canadian firms found a negative relationship between cash and MTB similar to that found by Afza and Adnan (2007) of non-financial Pakistani firms

A positive relationship is expected between cash holdings and Market to book ratio if the firms are managed efficiently.

\subsubsection{Effect of Firm Size on Cash Holding}

There is general agreement that firm size and cash holding are negatively related. Several models developed to determine optimal cash holding (Baumol, 1952; Miller and Orr, 1966: Mulligan, 1997) posit that large firms enjoy economies of scale and are therefore able to hold low cash levels than small firms(Garcia-Teruel \& Martinez-Solano, 2008). Opler et al. (1999) studying US firms finds that smaller firms with more investment opportunities and risky activities possess a larger proportion of liquid financial assets.

Apart from the economies of scale argument, the other reason that has been advanced as driving higher cash holding by small firms is information asymmetry which is deemed to be higher for small firms. The higher information asymmetry thus makes it difficult for small firms to raise funds from external sources and therefore most of them comparatively end up holding more cash than large firms.

Small firms have also been found to hold more cash because of financial constraints that they face and the higher risk of financial distress.

In studies where the relationship has been found to be positive it has been attributed to agency problem (Bates et al., 2009) and level of maturity of firms (Saddour, 2006). In times of financial crisis firms of all sizes are found to increase cash holding (Lee and Song, 2007) because of the prevailing financial constraints in the markets.

Saddour (2006) finds that for growing French companies there is a negative relationship between cash and size, however the cash level of mature companies increases with size. Afza and Adan (2007) reports a negative relationship between cash holding and size for Pakistan firms. From a study of Swiss firms Drobetz and Grüninger (2007) report an inverse relationship between firm size and cash holdings.

\subsubsection{Effect of Leverage on Cash Holding}

Leverage or debt ratio shows the extent to which a firm is using debt capital in its financing structure. Higher ratios imply that a firm has a higher ability to issue debt and therefore the expected relationship to cash holding will be an inverse one. Proponents of this line of thought explain that instead of holding large volumes of cash and cash equivalents (marketable securities), firms would instead issue debt (John, 1993). To support the argument further, Baskin (1987) argues that it becomes costlier to finance liquidity at high levels and therefore firms with high debt levels would reduce their liquidity as a way of managing the cost of liquidity.

However the relationship between cash and leverage is not a straight forward. Some studies such as Guney et al., (2007) found a negative relationship between cash and leverage at low levels of debt however as debt increased the relationship turned positive. The different variability pattern is attributed to low transaction cost at low levels of debt but as debt increases the impact of high potential distress cost kick in and as a consequence the firm increase cash holding to ward off potential risk of bankruptcy.

Harford et al., (2014) document a relationship between corporations' refinancing risk and cash holdings. More specifically, they found that firms with shorter-maturity debt hold more cash to compensate for the refinancing risk. Saddour (2006) found cash levels negatively affected by leverage for both growing and mature French companies.

Borhanuddin and Pok (2011) find that leverage significantly varies negatively with cash in Malaysian firms. The implication of this is that debt acts as an alternative to cash holding. Within their sample they also report that corporate governance has an impact on cash holding with those firms that have poor corporate governance 
holding more cash and vice versa.

\subsubsection{Effect of Cash Flow on Cash Holding}

Ferreira and Vilela (2004), Afza and Adnan (2007), Drobetz and Grüninger (2007), Alam et al., (2011) and Rizwan and Javed(2011) all report a positive relationship between cash flows and corporate cash holding. This is consistent with the tradeoff theory. On the other hand other authors have found a negative relationship for instance, Kim et al., (1998) found a negative relationship and concluded that this could be as a result of firms treating cash flow as a source of liquidity and therefore applying it as a substitute for cash holding. Riddick and Whited (2009) find that corporate cash holding and cash flows are negatively related and they attribute this to the firm's tendency to lower cash holding in order to invest once they project positive cash flows. In a similar line of thought Bao, Chan and Zhang (2012) report that cash flow sensitivity of corporate cash holding is negative when a firm faces negative cash flows. They also affirm the results in both financially constrained firms and those that are not constrained.

\subsubsection{Mediating Effect of Interest Rates on Cash Holding}

The effect of interest rates on cash holding is rooted in the liquidity preference theory. Early scholars such as Baumol(1952) and Tobin(1956) recognize that cash is needed to facilitate transactions as and when they are due and that such transaction demand for cash holding depends and varies inversely with the prevailing interest rates(Stone,Gup and Lee, 2013). In a separate study Meltzer (1963) conclude that non-human wealth (IRR on investment projects) and interest rates play an important role in explaining the demand and velocity for real cash balances. He further states that the interest rates negatively vary with the marginal propensity to hold cash.

Ferreira \& Vilela (2004) found evidence that cash levels increase during recessions, especially for financially constrained firms and that T-Bill rate is a significant determinant of cash holdings. Bates, et al. (2009)

Garcia-Teruel and Martinez-Solano (2008) measure the opportunity cost of investment in cash for small and medium sized firms in Spain and find that the difference between the return on a firms investments and the return on treasury bills is negatively related to cash holding.

Stone et al., (2013) studies the relationship between market rates of interest and corporate cash holdings over the 1970-2011 period. They do not find the expected negative relationship over the study period and conclude that the relationship is driven by several factors that they were unable to test for and that there exists a puzzle among the interest rates and cash holdings in the 1980's and the 1990's.

\subsubsection{Moderating Effect of Industry Sector on Cash Holding}

Nguyen (2006) report that cash holding is positively associated with firm level but negatively related to industrial risk for Japanese companies. Bates et al., (2009) find that firms in industries with high idiosyncratic risk such as those in high tech firms held more cash than manufacturing firms

In a study of the effect of cash holding on firm competitiveness, Fresard (2010) reports that cash holding do not only improve a firms competitiveness but that there is noticeable differential effect on the market share growth for firms in competitive markets as compared to those in concentrated markets by a margin as high as two times. Qiu and Wan (2014)report that the impact of technological spill overs(involuntary leakage or transmissions of knowledge among firms) on cash holding is more pronounced in firms with greater market changes such as the mobile phone or computers industry.

\subsection{Theoretical Review}

This study is based on the three theories of cash holding. These are the Tradeoff theory (Myers 1977), the financial hierarchy theory (Myers and Majluf, 1984) and the free cash flow theory (Jensen, 1986). Under the trade off theory firms seek an optimal level of cash holding by equating the marginal cost and benefits of holding cash. The financial hierarchy theory does not propose an optimal level of cash holding but rather holds that cash holding is a consequence of the financing structure of a firm. Thus when a firm is faced with attractive investment opportunities they will first finance them from internal sources (retained earnings) before resorting to external sources (debt and equity). The free cash flow theory on its part proposes that because of the agency problem between managers and owners' managers have an incentive to hoard cash to increase the amount of assets under their control and to gain discretionary power over the firm investment decision.

The expected relationship between determinants of cash holding under the three different theories are as under: 
Table 1. Summary of model predictions

\begin{tabular}{llll}
\hline Variable & Trade of Theory & Pecking Order theory & Free cash flow theory \\
\hline Market to Book Ratio & Positive & Positive & Negative \\
Leverage & Unknown & Negative & Negative \\
Real size & Negative & Positive & Positive \\
Cash flow & Negative & Positive & \\
Interest rates & Negative & Negative & \\
Industry & Unknown & Unknown & Unknown \\
\hline
\end{tabular}

\section{Method}

The study applied co-relational and non-experimental research design. This is consistent with previous studies in this area (Afza \& Adnan, 2007; Gill \& Shah, 2012; Ogundipe et al., 2012). The population of interest consisted of all non-financial companies listed on the Nairobi Securities Exchange (NSE). A census survey was applied to establish the determinants of cash holding among all 44 non-financial firms listed in NSE between 2002 and 2013 was done. Out of the 44 firms, only 38 non-financial firms were used in the analysis as they had full data available for at least one full year over the review period. Following the approach of Saddour (2006) and Garcia-Teruel and Martiez-Solano (2008) we proceeded to examine cash holding correlates under two regression methodologies. First, we pool all the cross-sectional units for the period under examination and estimate it using the ordinary least squares technique (OLS) with the year and industry dummies. The second approach was the use of fixed and random effects panel data models given the nature of the data. In this approach, we estimate a linear panel regression model as proposed by Green (2008). This methodology is robust as it takes into account observable heterogeneity which the OLS model does not and hence its results are robust. We, therefore, estimate the following models

We estimate the following model under the OLS (equation 1) and Panel data models (equation 2).

$$
\begin{gathered}
\text { C. } H_{t}=\alpha+\beta 1 . M T B_{t}+\beta 2 . \text { Size }_{t}+\beta 3 . \text { Lev }_{t}+\beta 4 . C . F_{t}+\beta 5 . I R_{t}+\beta 6 . I . D_{t}+\mu_{t} \\
\text { C. } H_{i, t}=\alpha+\beta 1 . M T B_{i, t}+\beta 2 . \text { Size }_{i, t}+\beta 3 . \text { Lev }_{i, t}+\beta 4 . C . F_{i, t}+\beta 5 . I R_{i, t}+\beta 6 . I . D_{i, t}+\mu_{i, t}
\end{gathered}
$$

Where C.H is a firm's cash holding, MTB is the firm's market-to-book ratio which is computed as a ratio of the sum of assets book value and value of market equity less the book value of equity divided by the book value of assets. The size of the firm is measured by the total assets of the firm in its natural logarithm form. Lev is the firm's leverage which is the sum of long-term debt and debt in current liabilities divided by the book value of total assets, C.F is the cash flow which is measures by net operational income plus depreciation divided by net assets, I.R is the interest rate which is the average quarterly 91 day Treasury bill rate, and I.D is the industry dummy while $\mu$ is the error term. The subscripts $i$ and t denotes cross-section unit and time respectively.

\section{Results}

\subsection{Descriptive Analysis}

Table 2 shows the descriptive statistics for all non-financial companies listed on the Nairobi Securities Exchange that was studied. The total number of observations on all Non-financial firms across the period covered by the study was 408 . The mean cash ratio of the full sample was 0.062 . The minimum average cash holding was -0.488 . The mean average market to book ratio was 1.496 . The mean of firm size (natural logarithm of total assets) for sampled firms was 15.129 with a standard deviation of 1.913 . The mean value of leverage was 0.517 while that of cash flows was 0.096 and that of interest rates was 0.074 .

Table 2. Descriptive Statistics for All Quoted Companies

\begin{tabular}{llllll}
\hline Variables & N & Min & Max & Mean & Std. Dev. \\
\hline Cash & 408 & -0.488 & 0.752 & 0.062 & 0.164 \\
MTB & 408 & 0.000 & 8.984 & 1.496 & 1.148 \\
SIZE & 408 & 0.000 & 19.056 & 15.129 & 1.913 \\
Leverage & 408 & -0.322 & 4.905 & 0.517 & 0.376 \\
CF & 408 & -0.606 & 0.954 & 0.096 & 0.131 \\
Interest rates & 408 & 0.016 & 0.148 & 0.074 & 0.029 \\
\hline
\end{tabular}




\subsection{Trend Analysis}

Figure 1 shows the cash ratio trend for the non-financial companies from the year 2002 to 2013 . The trend line indicates that cash ratio has been on the decline as indicated by a negative slope of the linear (cash ratio) line fitted to the cash ratio values over the period. However, we observe a cyclical increase in cash holding for non-financial firms that sort of peaks around the periods 2002, 2007 and 2013. These were election years, and it could be that firms shower up their cash balances due to uncertainty related to the electioneering period. The overall decline is puzzling as it seems not consistent with trends in cash holding in other markets where previous studies have indicated a general increase in cash holding.

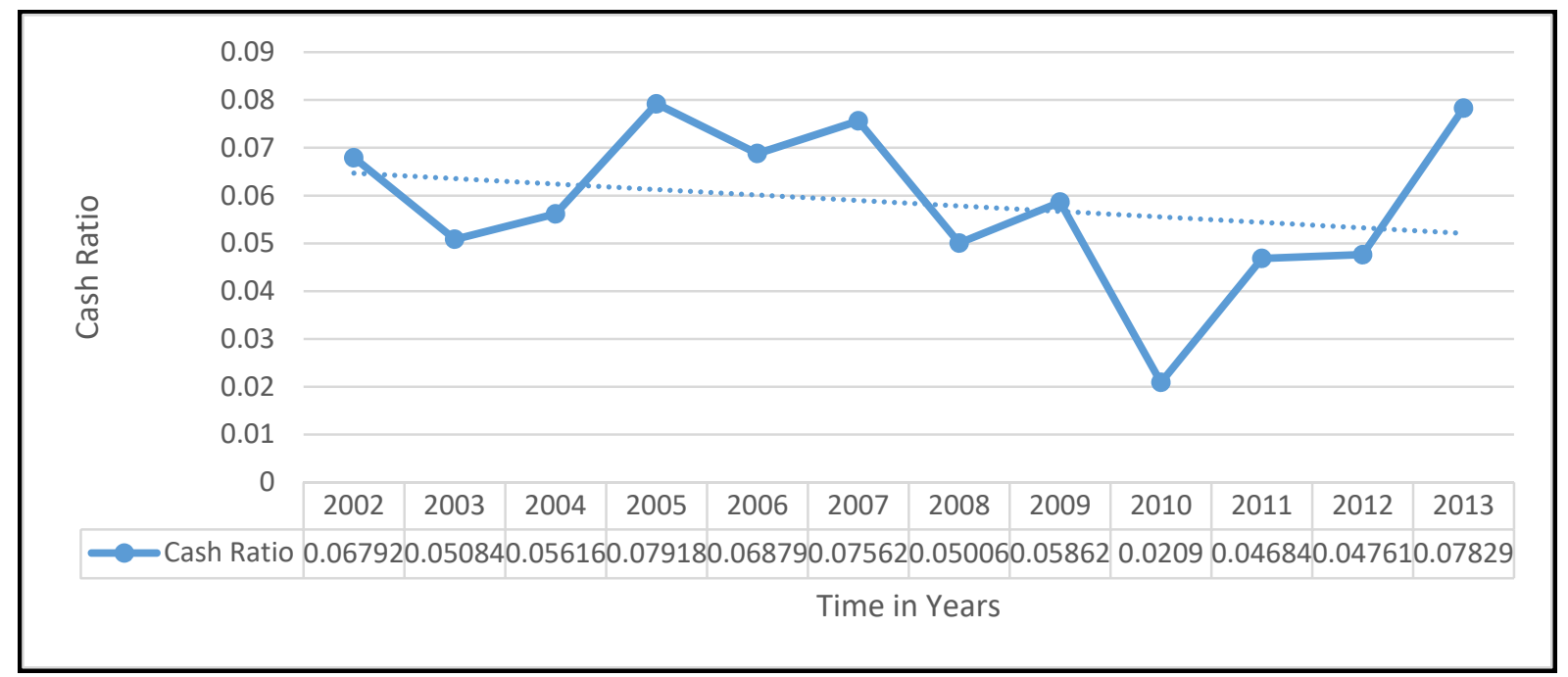

Figure 1. Cash ratio movements (2002-2013)

\subsection{Regression Analysis of Cash Holding Determinants}

Table 2 indicates results of the overall regression model fitted. The regression results show that cash flows is the only variable that is significantly and positively related to cash ratio of the firms. Thus, cash flow has a significant positive relationship with cash holding of the non-financial companies listed on the NSE. Consistent with the result of individual characteristics (which we present in subsequent sections) we do not find a high R-squared (0.168) which indicates that only 16.8 percent of the changes in the cash holding of the firms studied are explained by changes in the explanatory variables making up the model. This therefore indicates there are other factors that explain the changes in cash holding of non-financial firms listed on the NSE, Kenya.

Table 3. Regression Model Based OLS, Fixed and Random Effects Models

\begin{tabular}{llll}
\hline & $\begin{array}{l}\text { OLS Regression } \\
\text { Model }\end{array}$ & Fixed Effects Regression Model & Random Effects Regression Model \\
\hline Market-to-Book Ratio & -0.0102 & -0.0122 & -0.0102 \\
& $(-1.64)$ & $(-1.06)$ & $(-0.98)$ \\
Firm Size & 0.0000283 & 0.00109 & 0.0000283 \\
& $(0.00)$ & $(0.26)$ & $(0.01)$ \\
Leverage & -0.0391 & -0.0384 & -0.0391 \\
& $(-1.35)$ & $(-0.61)$ & $(-0.62)$ \\
Cash Flow & $0.521^{* * *}$ & $0.534^{* *}$ & $0.521^{* * *}$ \\
& $(6.78)$ & $(3.88)$ & $(3.70)$ \\
Interest Rates & 0.116 & 0.386 & 0.116 \\
& $(0.40)$ & $(0.60)$ & $(0.43)$ \\
ISector_2 & -0.0430 & $-0.0437^{*}$ & $-0.0430^{*}$ \\
& $(-1.21)$ & $(-2.26)$ & $(-2.26)$ \\
ISector_3 & 0.0145 & 0.0144 & 0.0145 \\
& $(0.49)$ & $(0.37)$ & $(0.37)$ \\
ISector_4 & 0.0171 & 0.0172 & 0.0171 \\
\hline
\end{tabular}




\begin{tabular}{llll}
\hline & $\begin{array}{l}\text { OLS Regression } \\
\text { Model }\end{array}$ & Fixed Effects Regression Model & Random Effects Regression Model \\
\hline & $(0.57)$ & $(0.85)$ & $(0.84)$ \\
_ISector_5 & 0.0398 & 0.0366 & 0.0398 \\
& $(1.06)$ & $(0.96)$ & $(1.04)$ \\
_ISector_6 & -0.0192 & -0.0203 & -0.0192 \\
& $(-0.50)$ & $(-0.83)$ & $(-0.81)$ \\
ISector_7 & 0.0432 & 0.0412 & 0.0432 \\
& $(1.47)$ & $(1.22)$ & $(1.26)$ \\
ISector_8 & -0.0888 & -0.0829 & -0.0888 \\
& $(-1.54)$ & $(-0.82)$ & $(-0.88)$ \\
_cons & 0.0244 & -0.00941 & 0.0244 \\
& $(0.27)$ & $(-0.15)$ & $(0.38)$ \\
$N$ & 408 & 408 & 408 \\
$R^{2}$ & 0.168 & 0.174 & \\
\hline
\end{tabular}

\subsubsection{Effect of Market-to-Book Ratio on Cash Holdings}

Using OLS, FGLS, REGLS, market to book ratio is positively related to cash holdings of the firm as estimated under OLS and Random effects model but negative under fixed effects model. In all the three methods as indicated in Table 4 it was established that the relationship was not statistically significant and thus the hypothesis is rejected. The cash holding of Kenyan companies does not, therefore, support the trade-off and Pecking order theories which predict a positive relationship between cash holding and available investment opportunities represented by the Market to book ratio. The majority of previous studies find a positive and significant relationship between Market to Book value ratio (MTB) and corporate cash holding. (Kim et al., 1998; Opler et al., 1999; Ferreira and Vilela, 2004; Ozkan and Ozkan, 2004; and Alam et al., 2011).

Table 4. Regression analysis on effect of market-to-book ratio on cash holdings

\begin{tabular}{llll}
\hline & OLS & Fixed Effects & Random Effects \\
\hline Market-to-Book Ratio & 0.000114 & -0.000858 & 0.000114 \\
& $(0.02)$ & $(-0.18)$ & $(0.02)$ \\
Constant & $0.0578^{* * *}$ & $0.0593^{* * *}$ & $0.0578^{* * *}$ \\
& $(4.93)$ & $(4.96)$ & $(4.93)$ \\
Number of Observations & 408 & 408 & 408 \\
Coef. of Determination $\left(R^{2}\right)$ & 0.000 & 0.000 & \\
\hline
\end{tabular}

Note. $t$ statistics in parentheses; ${ }^{*} p<0.05,{ }^{* *} p<0.01,{ }^{* * *} p<0.001$

\subsubsection{Effect of Firm Size on Cash Holdings}

The second objective was to analyze the effect of firm size on the cash holding of firms listed on the NSE. The study results as indicated in Table 5 indicate that there is an insignificant positive relationship between size and cash holding. Meaning size was not a significant determinant of cash holding of Non-financial firms listed on the NSE. The positive relationship between cash holding and real size is expected under the pecking order theory because as explained by Saddour (2006) that larger firms have a high level of operational cash flow. Therefore, they increase their cash holdings, and the relationship between cash holdings and size is expected to be positive. The finding above is not consistent with previous findings by Ferreira \& Vilela (2004), Nguyen (2006) and Drobetz and Gruninger (2007) all who reported a negative relationship between cash holding and size of the firm. 
Table 5. Regression analysis on effect of firm size on cash holdings

\begin{tabular}{llll}
\hline & OLS & Fixed Effects & Random Effects \\
\cline { 2 - 4 } Firm Size & 0.00244 & 0.00353 & 0.00244 \\
Constant & $(0.48)$ & $(0.65)$ & $(0.48)$ \\
& 0.0210 & 0.00442 & 0.0210 \\
Number of Observations & $(0.27)$ & $(0.05)$ & $(0.27)$ \\
Coef. of Determination $\left(R^{2}\right)$ & 0.001 & 0.001 & 408 \\
\hline
\end{tabular}

Note. $t$ statistics in parentheses; ${ }^{*} p<0.05,{ }^{* *} p<0.01,{ }^{* * *} p<0.001$.

\subsubsection{Effect of Leverage on Cash Holdings}

The findings as indicated in Table 6 indicate that there exists a significant negative effect between leverage and cash holding. The implication is that as leverage increases the cash holding of non-financial firms' decreases and vice versa. The results reported in this study are consistent with previous results in other parts of the world such as Saddour (2006) France, Afzan and Adan (2007) and Rizwan and Javed (2010) all in Pakistan, Hardin III et al., (2009) USA and Megisnson and Wei (2010) for Chinese companies. On the contrary, a positive relationship between leverage and cash holding have been reported in a few studies such as one on American SMEs by Faulkender (2004) who reported positive relationship and Garcıa-Teruel and Martınez-Solano (2008) who report a positive for SME's in Spain.

Table 6. Regression analysis on effect of leverage on cash holdings

\begin{tabular}{llll}
\hline & OLS & Fixed Effects & Random Effects \\
\cline { 2 - 4 } Leverage & $-0.0492^{*}$ & $-0.0529^{*}$ & $-0.0492^{*}$ \\
Constant & $(-2.04)$ & $(-2.15)$ & $(-2.04)$ \\
& $0.0835^{* * *}$ & $0.0854^{* * *}$ & $0.0835^{* * *}$ \\
Number of Observations & $(5.41)$ & $(5.45)$ & $(5.41)$ \\
Coef. Of Determination $\left(R^{2}\right)$ & 0.010 & 0.012 & 408 \\
\hline
\end{tabular}

Note. $t$ statistics in parentheses; ${ }^{*} p<0.05,{ }^{* *} p<0.01,{ }^{* * *} p<0.001$.

\subsubsection{Effect of Cash Flows on Cash Holdings}

Table 7 shows that there exists a positive relationship between the cash flow and cash holding implying, therefore, that an increase in the cash flows leads to an increase in cash holdings of the firm. This finding is consistent with the pecking order theory but not the tradeoff theory which predicts a negative relationship between cash flow and cash holding. The results are consistent with those of Ferreira and Vilela (2004), Afza and Adnan (2007), Alam et al. (2011), Ongudipe et al. (2012) and Al-Armerneh (2013) all who found a positive relationship between cash holding and cash flow.

Table 7. Regression Analysis on Effect of Cash Flows on Cash Holdings

\begin{tabular}{|c|c|c|c|}
\hline & OLS & Fixed Effects & Random Effects \\
\hline \multirow[t]{2}{*}{ Cash Flows } & $0.482^{* * *}$ & $0.484^{* * *}$ & $0.482^{* * *}$ \\
\hline & $(7.37)$ & $(7.31)$ & $(7.37)$ \\
\hline \multirow[t]{2}{*}{ Constant } & 0.0115 & 0.0113 & 0.0115 \\
\hline & $(1.08)$ & $(1.06)$ & $(1.08)$ \\
\hline Number of Observations & 408 & 408 & 408 \\
\hline Coef. Of Determination $\left(R^{2}\right)$ & 0.118 & 0.119 & \\
\hline
\end{tabular}

Note. $t$ statistics in parentheses; ${ }^{*} p<0.05,{ }^{* *} p<0.01,{ }^{* * *} p<0.001$.

\subsubsection{Mediating Effect of Interest Rates on Cash Holdings}

Using stepwise regression, the Sobel Goodman test the results shows that the interest rates positively mediates 
the relationship between cash holdings and MTB, size and cash flow but negative for leverage. Further, the results showed that interest rate moderation had a significant effect on size, cash flows, and leverage but was established to be insignificant in relation to MTB. Delving further into analysis of the mediating effect we find that the impact is significant on size (negative impact) and on leverage (positive impact) and is insignificant on MTB and cash flow. In conclusion, we partly fail to reject the null hypothesis as far as the impact of interest rates on the relationship between (i) cash and size (ii) cash and leverage. The null hypothesis is however rejected on the expected impact of interest rates on cash \& MTB and cash \& cash flow.

Table 8. Regression analysis on effect of interest rates on cash holdings

\begin{tabular}{|c|c|c|c|c|c|c|}
\hline & Fixed Effects & t-stat & $\begin{array}{l}\text { Random } \\
\text { Effects }\end{array}$ & t-stat & OLS & t-stat \\
\hline MTB & -0.0341 & -1.91 & -0.0334 & -1.88 & $-0.0484^{*}$ & -2.14 \\
\hline SIZE & $-0.0328^{* *}$ & -2.79 & $-0.0191^{*}$ & -2.23 & -0.00303 & -0.50 \\
\hline Leverage & $0.205^{* * *}$ & 3.43 & $0.196^{* *}$ & 3.28 & 0.148 & 1.93 \\
\hline $\mathrm{CF}$ & $0.494^{* *}$ & 2.93 & $0.556^{* * *}$ & 3.31 & $0.960^{* * *}$ & 4.66 \\
\hline Interest rate mediation on MTB & 0.259 & 1.06 & 0.270 & 1.11 & 0.555 & 1.77 \\
\hline Interest rate mediation on Size & $0.0939^{* *}$ & 2.81 & $0.0901^{* *}$ & 2.69 & 0.0816 & 1.87 \\
\hline Interest rate mediation on Leverage & $-2.615^{* *}$ & -3.24 & $-2.594^{* *}$ & -3.20 & $-2.717^{*}$ & -2.59 \\
\hline Interest rate mediation on $\mathrm{CF}$ & -2.857 & -1.39 & -3.139 & -1.52 & $-5.744^{*}$ & -2.20 \\
\hline Constant & $0.442^{*}$ & 2.52 & 0.234 & 1.84 & 0.00174 & 0.02 \\
\hline Number of Observations & 408 & & 408 & & 408 & \\
\hline Coef. of Determination $\left(R^{2}\right)$ & 0.099 & & & & 0.163 & \\
\hline
\end{tabular}

Note. ${ }^{*} p<0.05,{ }^{* *} p<0.01,{ }^{* * *} p<0.001$.

\subsubsection{Effect of industry sector on cash holdings}

The sixth objective investigated if there were any significant differences between industrial sectors regarding the cash holding practices. The results show that there are significant differences in the cash holding practices among firms in the different sectors. This is consistent with other studies that have confirmed an influence of industry sector on firm cash holding. Nguyen (2006) report that cash holding is positively associated with firm level but negatively related to industrial risk for Japanese companies. Bates et al., (2009) reports higher cash balances for high tech companies compared to manufacturing firms.

Table 9. Regression Analysis on Effect of Industry Sectors on Cash Holdings

\begin{tabular}{lllllll}
\hline & Fixed Effects & t-stat & Random Effects & t-stat & OLS & t-stat \\
\hline MTB & -0.0121 & -1.88 & -0.0103 & -1.66 & -0.0103 & -1.66 \\
Size & 0.00114 & 0.18 & 0.000208 & 0.03 & 0.000208 & 0.03 \\
Leverage & -0.0389 & -1.32 & -0.0388 & -1.34 & -0.0388 & -1.34 \\
CF & $0.534^{* * *}$ & 6.84 & $0.522^{* * *}$ & 6.81 & $0.522^{* * *}$ & 6.81 \\
_Iindustrys_2 & -0.0439 & -1.22 & -0.0431 & -1.21 & -0.0431 & -1.21 \\
_Iindustrys_3 & 0.0147 & 0.49 & 0.0146 & 0.49 & 0.0146 & 0.49 \\
_Iindustrys4 & 0.0172 & 0.56 & 0.0171 & 0.57 & 0.0171 & 0.57 \\
_Iindustrys_5 & 0.0364 & 0.95 & 0.0393 & 1.04 & 0.0393 & 1.04 \\
_Iindustrys_6 & -0.0196 & -0.50 & -0.0188 & -0.49 & -0.0188 & -0.49 \\
_Iindustrys_7 & 0.0412 & 1.39 & 0.0430 & 1.46 & 0.0430 & 1.46 \\
_Iindustrys_8 & -0.0826 & -1.41 & -0.0885 & -1.53 & -0.0885 & -1.53 \\
_cons & 0.0185 & 0.20 & 0.0302 & 0.34 & 0.0302 & 0.34 \\
Number of Observations & 408 & & 408 & & 408 & \\
Coef. of Determination $\left(R^{2}\right)$ & 0.173 & & & & 0.168 & \\
\hline
\end{tabular}

Note. ${ }^{*} p<0.05,{ }^{* *} p<0.01,{ }^{* * *} p<0.001$.

\section{Discussion}

The objective of the study was to establish the determinants of cash holding among listed non-financial firms on 
the NSE for the period 2003 to 2013.

The first objective of the study was to investigate the relationship between Market-to-Book (MTB) ratio on cash holding of non-financial companies listed on the NSE. Using OLS, FGLS, REGLS, and MTB ratio was found to be positively related to cash holdings of the firm as estimated under OLS and Random effects model but negative under fixed effects model. In all the three methods it was established that the relationship was not statistically significant

Majority of previous studies find a positive and significant relationship between Market to Book value ratio (MTB) and corporate cash holding. (Kim et al., 1998; Opler et al., 1999; Ferreira and Vilela, 2004; Ozkan and Ozkan, 2004; and Alam et al., 2011). This support the trade off and pecking order theories in that firms with plenty of investment opportunities will hold more cash.

But inverse relationship of MTB with corporate cash holdings is also reported in other studies (Jani et al., 2004; Bates et al., 2009), which corresponds to agency theory. Afza and Adnan (2007) study conducted in Pakistan indicated that the Cash holding and Market-to-book ratio of the firms are negatively related. Gill and Shah (2012) also found a negative relationship between cash holding and MTB of Canadian firms.

The cash holding of Kenyan companies do not therefore support the Trade off and Pecking order theories which predict a positive relationship between cash holding and available investment opportunities represented by the MTB ratio.

The findings could however support the free cash flow theory where the MTB ratio is expected to have a negative relationship with the cash holdings of the firm. Such conclusion is however not absolute as the coefficient was not statistically significant.

The inconclusive nature of our findings could also be explained by the findings by Dittmar \& Duchin (2009) where they explain that when shareholder protection is poor, factors that generally drive the need for cash holdings, such as investment opportunities and asymmetric information, actually becomes less important.

The second objective was to analyze the effect of firm size on the cash holding of firms listed on the NSE. The study measured size by the natural logarithm of total assets. Size was used as a proxy for access to capital markets. This means that as firms grow in size they build economies of scale that they can leverage to attract external funding at comparatively favorable terms than are small companies that are yet to prove their mettle. The study established that there is an insignificant positive relationship between size and cash holding. Inverse relationship between cash firm size and cash flow supports the tradeoff theory Dittmar et al. (2002), Ferreira and Vilela (2004), and Guney et al. (2003). Positive relationship between cash holding and real size is expected under the pecking order theory because as explained by Saddour (2006), larger firms have high level of operational cash flow. Therefore they increase their cash holdings and the relationship between cash holdings and size becomes positive. The finding above are not consistent with previous findings by Ferreira \& Vilela (2004), Nguyen(2005) and Drobetz and Gruninger (2007) all who reported negative relationship between cash holding and size of the firm.

Other factors could also play to give different results for as reported by Saddour (2006) that for growing companies' cash holding was negatively related to size whereas for mature companies in his study of French companies' cash holding was positively related to firm size. Supporting this argument Ozkan and Ozkan (2004) after reporting inconclusive results in their studies point out that other factors may affect the way in which a company's size affects its cash holding decisions.

The third objective of the study was to investigate the effect of leverage on the cash holding of nonfinancial companies listed on the NSE, Kenya. Leverage was measured by the ratio of total debt to net assets (debt ratio). The findings indicate that a significant negative relationship between leverage and cash holding. From previous studies for large firms (Kim et al., 1998; Opler et al., 1999; Ferreira \& Vilela, 2004; Ozkan \& Ozkan, 2004) it is reported that more highly leveraged firms should maintain lower cash holdings because they incur higher interest rates (Baskin, 1987) and have easier access to the capital markets (John, 1993). Garcia-Teruel and Martınez-Solano (2008).

The results reported in this study are also consistent with previous results in other parts of the world such as Saddour (2006) France, Afzan and Adan (2007) and Rizwan and Javed (2010) all in Pakistan, Hardin III et al (2009) USA and Megisnson and Wei( 2010) for Chinese companies.

Positive relationship between leverage and cash holding have been reported in a few studies such as one on American SMEs by Faulkender (2004) and Garcia-Teruel and Martınez-Solano (2008) who indicated in their study of SME's in Spain that it appears that SMEs prefer to keep high cash levels rather than use the cash to 
reduce their debt, given their greater difficulty in gaining access to the capital markets. On the other hand, Ozkan and Ozkan (2004) also consider that more highly leveraged firms may keep more cash in order to lower their default risk

According to the trade-off theory, leverage can have a positive or a negative effect on the cash level; however pecking order theory and free cash flow stipulates a negative one. The results show a negative relation between cash holding and leverage for non-financial companies listed on the NSE. This provides evidence for the three theories.

The fourth objective was to establish the effect of cash flow on the cash holding of the nonfinancial firms whose shares are quoted on the NSE. Cash flow was measured by the ratio of cash flow from operations divided by the net assets of the firm. The results of the study indicate a positive relationship between the cash flow and cash holding. Increase in cash flow from operations was related to higher cash holding of the firms.

The tradeoff theory predicts a negative relationship between cash flow and cash holding this is because firms can use their cash flow as a source of liquidity to finance their investments. Thus cash flow can be seen as a cash substitute and would be negatively correlated to cash level.

The pecking order theory predicts a positive relationship between cash holding and cash flow. This is because when operational cash flow are high, firms use them to finance new profitable projects, to repay debts, to pay dividends and finally to accumulate cash. Thus, one could expect cash holdings to increase with cash flow level.

The finding supports the pecking order theory of cash but not the tradeoff theory which predicts a negative relationship between cash flow and cash holding. The results are consistent with those of Ferreira and Vilela (2004), Afza and Adnan (2007), Alam et al. (2011), Ongudipe et al. (2012) and Al-Armerneh (2013) all who found positive relationship between cash holding and cash flow.

Kim et al., (1998) report an inverse relationship and explain that firms consider cash flows as a source of liquidity and use it as a substitute to cash holding as explained above. (Garcia-Teruel et al., 2008).

The fifth objective was to establish whether prevailing interest rates had a mediating effect on between the independent variables and cash holding of non-financial firms listed on the NSE. Using stepwise regression, the sobel goodman test the results shows that the interest rates positively mediates the relationship between cash holdings the dependent variable and MTB, size and cash flow but negative for leverage.

Negative relationship between cash and interest rates have been reported by Tobin (1956), Meltzer (1963), Garcia-Teruel and Martinez-Solano (2008) and Bates et al. (2009) .Ferreira and Vilela (2004) found evidence that cash levels increase during recessions for financially constrained firm and concluded that but that the one-month T-Bill rate is a significant determinant of cash holdings.

The finding on the mediating of interest rates of the relationship between cash holding and the independent variables is novel.

The sixth objective investigated if there were any significant differences between sectors regarding the cash holding practices. The results show that there are significant difference in the cash holding among firms in the different sectors. However when moderation effect of industry sector on the independent variables was tested, the results showed that the industry sector moderation on the MTB, size, leverage and cash flow is not significant.

Other empirical studies have confirmed an influence of industry sector on cash holding. Zhou (2009) concludes that high technology firms increased their cash holdings more significantly than firms in other industries. Nguyen (2005) reports that cash holding is positively associated with firm level but negatively related to industrial risk for Japanese companies.

Bates et al., (2009) report that the average cash ratio of high-tech firms is greater than the average cash ratio of manufacturing firms by a factor of over two times. Fresard (2010) report that firms in highly competitive industries leverage their cash levels as a strategic weapon to gain market share. From the findings industry sector is thus more of a direct determinant of the cash holding of firms rather than a moderating factor.

In conclusions the findings reveal that firms MTB ratio and firm size are an insignificant predictors of cash holding. The results also show that leverage is negatively related to cash holdings implying that a trade-off exists between cash holding and leverage which is consistent with the tradeoff, pecking order and free cash flow theories of cash holding. Positive significant relationship between cash flow and cash holding was confirmed for nonfinancial firms listed on the NSE. This lends support to the pecking order theory behavior. It was established that prevailing interest rates are a significant mediator of the relationship between cash holding and MTB, size, 
cash flow and leverage and that the industrial sector in which a firm operates influences the cash holding policies.

\section{Limitations and Suggestions for Further Research}

From the results of our study there are various opportunities for further study in the cash holding space. Some of the results in this study did not support previous findings on the study variables as predicted and will thus call for further analysis and investigation to understand the finding. Some of the areas to enrich research findings would be to bring in study variables that consider corporate governance attributes such as ownership concentration, Board size and board independence. The overall $\mathrm{R}$ squared in the study was law indicating existence of other factors that influence cash holding a study could be carried out to establish the relationship between cash and other firm characteristics that were not considered such as dividend payments, sales ratio and working capital. It would also be useful for a study to be extended to private firms to compare the results with the sample of public firms. Finally, a comparative study can be done on the determinants of cash holdings across the East Africa Community (EAC) countries as the current study was limited to companies operating in Kenya only.

\section{References}

Afza, T., \& Adnan, S. M. (2007). Determinants of corporate cash holdings: A case study of Pakistan. In Proceedings of Singapore Economic Review Conference (SERC).

Alam, H. M., Ali, L., Rehman C. A., \& Akram M. (2011). The impact of working capital management on profitability and market valuation of Pakistani firms. European Journal of Economics, Finance \& Administrative Sciences, 32.

Al-Amarneh, A. (2013). Why do Jordanian firms hold cash? An empirical examination of the industrial companies listed in ASE. International Journal of Academic Research, 5(1), 103-111.

Bao, D., Chan, K. C., \& Zhang, W. (2012). Asymmetric cash flow sensitivity of cash holdings. Journal of Corporate Finance, 18(4), 690-700.

Baskin, J. B. (1987). Corporate liquidity in games of monopoly power. The Review of Economics \& Statistics, 69(2), 312-319.

Bates, T., Kahle, K., \& Stulz, R. (2009). Why Do U.S. Firms Hold So Much More Cash than They Used to? The Journal of Finance, 15(5).

Baumol, W. J. (1952). The transactions demand for cash: An inventory theoretic approach. The Quarterly Journal of Economics, 545-556.

Benoit, J. P. (1984). Financially constrained entry in a game with incomplete information, Rand Journal of Economics, 15, 490-499.

Bigelli, M., \& Vidal, J. (2012). Cash Holdings in Private Firms. Journal of Banking and Finance, 36(1), 26-35.

Bolton, P., \& Scharfstein. (1990). A theory of predation based on agency problems in financial contracting. American Economic Review, 80, 93-106

Borhanuddin, R., \& Pok Wee, C. (2011). Cash Holdings, Leverage, Ownership Concentration and Board Independence: Evidence from Malaysia. Malaysian Accounting Review, 10(1), 63-88.

Campello, M. (2006). Debt financing: Does it boost or hurt firm performance in product markets? Journal of Financial Economics, 82(1), 135-172.

Daher, M. (2010). Determinants of cash holding in UK public and private firms. MREs Thesis Lancaster University Unpublished Accessed online.

DeAngelo, H., \& DeAngelo, L. (2007). Capital Structure, Payout Policy, and Financial Flexibility. University of Southern California working paper.

Dittmar, A. K., \& Duchin, R. (2010). The Dynamics of Cash. Ross School of Business Paper No. 1138.

Dittmar, A., \& Smith, J. (2007). Corporate Governance and value of cash holdings. Journal of Financial economics, 83, 599-634.

Dittmar, A., Mahrt-Smith, J., \& Servaes, H. (2003). International corporate Governance and corporate cash holdings. Journal of Financial and Quantitative Analysis, 38(1) 111-133

Drobetz, W., \& Grüninger, M. C. (2007). Corporate cash holdings: Evidence from Switzerland. Financial markets Portfolio, 21, 293-324. 
Duchin, R. (2010). Cash Holdings and Corporate Diversification. Journal of Finance, 65(3), 955-992.

Faulkender M, Wang R, 2006. Corporate Financial Policy and the Value of Cash. The Journal of Finance, (4), 1957-1990.

Ferreira, M. A., \& Vilela, A. S. (2004). Why Do Firms Hold Cash? Evidence from EMU Countries. European Financial Management, 10(2), 295-319. http://dx.doi.org/10.1111/j.1354-7798.2004.00251.x

Fresard, L. (2010). Financial Strength and Product Market Behavior: The Real Effects of Corporate Cash Holdings. Journal of Finance, 65(3), 1097-1122.

García-Teruel, P. J., \& Martínez-Solano, P. (2008). On the Determinants of SME Cash Holdings: Evidence from Spain. Journal of Business Finance \& Accounting, 35(1/2).

Gill, A., \& Shah, C. (2012). Determinants of corporate cash holdings: evidence from Canada. International Journal of Economics and Finance, 4(1), 70. http://dx.doi.org/10.5539/ijef.v4n1p70

Guney, Y., Ozkan, A., \& Ozkan, N. (2003) Additional international evidence on corporate cash holdings. EFMA Helsinki meetings.

Hardin III, W., Highfield, M., Hill, M., \& Kelly, G. G. (2009). The Determinants of REIT Cash Holdings. Journal of Real Estate Finance \& Economics, 39(1), 39-57.

Harford, J., Klasa, S., \& Maxwell, W. F. (2014). Refinancing Risk and Cash Holdings. Journal of Finance, 69(3), 975-1012.

Jani, E., Hoesli, M., \& Bender, A. (2004). Corporate cash holdings and agency conflicts.

Jensen, M. C. (1986). Agency costs of free cash flow, corporate finance, and takeovers. The American Economic Review, 76(2), 323-329.

Kalcheva, I., \& Lins, K. V. (2003) International Evidence on Cash Holdings and Expected Managerial Agency Problems. Review of Finance, 20, 1087-1112.

Kim, C. S., Mauer, D. C., \& Sherman, A. E. (1998). The determinants of corporate liquidity: Theory and evidence. Journal of Financial and Quantitative Analysis, 33, 335-359.

Kusnadi, Y., \& Wei, K. C (2011). The determinants of Corporate Cash management policy: Evidence from around the world. Journal of Corporate Finance, 17(3), 725-740.

Lee, C., \& Lee, K. W. (2010). Cash Holdings, Corporate Governance Structure and Firm Valuation. Retrieved http://dx.doi.org/10.2139/ssrn.1536481

Lee, Y., \& Song, K. (2007). Why have East Asian Firms Increased Cash Holdings so much after the Asian Financial Crisis? 20th Australian Finance \& Banking Conference 2007.

Martínez-Sola, C., García-Teruel, P. J., \& Martínez-Solano, P. (2013).Corporate cash holding and firm value. Applied Economics, 45(2), 161-170.

Megginson, W. L., \& Wei, Z. (2010). Determinants and value of cash holdings: Evidence from China's privatized firms. SSRN Working Paper Series, 1-37.

Meltzer, A. H. (1963). The demand for money: the evidence from the time series. Journal of Political Economy, 71(3), 219-246.

Miller, M. H., \& Orr, D. (1966). A Model of the Demand for Money by Firms. The Quarterly Journal of Economics, 80(3), 413-435.

Morais, F., \& Silva, P. (2013). Determinants of cash holdings in the accommodation industry. Tourism and Hospitality International Journal, 1, 95-136.

Mulligan, C. B. (1997). Scale Economies, the Value of Time, and the Demand for Money: Longitudinal Evidence from Firms. The Journal of Political Economy, 105, 1061-1079.

Myers, S. C., \& Majluf, N. S. (1984). Corporate financing and investment decisions when firms have information that investors do not have. Journal of Financial Economics, 13(2), 187-221.

Nguyen, P. (2006). How sensitive are Japanese firms to earnings risk? Evidence from cash holdings. http://dx.doi.org/10.2139/ssrn.889502

Ogundipe, L. O., Ogundipe, S. E., \& Ajao, S. K. (2012), Cash Holding and Firm Characteristics: Evidence from Nigerian Emerging Market. Journal of Business, Economics, 1(2). 
Opler, T., Pinkowitz, L., Stulz, R., \& Williamson, R. (1999). The determinants and implications of corporate cash holdings", Journal of Financial Economics, 52, 3-46.

Ozkan, A., \& Ozkan, N. (2004). Corporate cash holdings: An empirical investigation of UK companies. Journal of Banking \& Finance, 28(9), 2103-2134.

Pinkowitz, L., Stulz, R., \& Williamson, R. (2006). Does the contribution of corporate cash holdings and dividends to firm value depend on governance? A cross-country analysis. Journal of Finance, 61, 2725-2751.

Qui, J., \& Wan, C. (2014). Technology spill overs and cash holdings. Journal of Financial Economics, 2(1), 1-16

Riddick, L. A., \& Whited, T. M. (2009). The corporate propensity to save. The Journal of Finance, 64(4), 1729-1766.

Rizwan, M. F., \& Javed, T. (2011). Determinants of corporate cash holdings: evidence from Pakistani corporate sector. Economics, Management and Financial Markets, 6(1), 344.

Saddour, K. (2006). The determinants and the value of cash holdings: Evidence from French firms. CEREG, $1-33$.

Sanchez, J. M., \& Yurdagul, E. (2013). Why are US firms holding so much cash? An exploration of cross sectional variation. Federal Reserve Bank of St Louis Review 95(4), 293-325

Stone, A. L., Gupta, B. E., \& Lee, J. (2013): Corporate Cash holding and Interest rates: 1970:2011. Discussion Paper. Retrieved from http://www.bama.au.edu

Tobin, J. (1956). The interest-elasticity of transactions demand for cash. Review of Economics and Statistics, $38(3), 241-247$.

\section{Copyrights}

Copyright for this article is retained by the author(s), with first publication rights granted to the journal.

This is an open-access article distributed under the terms and conditions of the Creative Commons Attribution license (http://creativecommons.org/licenses/by/4.0/). 